\title{
Construction of a cDNA Library of Vitis pseudoreticulata Native to China Inoculated with Uncinula necator and the Analysis of Potential Defence-related Expressed Sequence Tags (ESTs)
}

Y. Xu $u^{1,2,3}, Z . Z^{1,2,3}$, Y. Xiao ${ }^{1,2,3}$ and Y. Wang ${ }^{* 1,2,3}$

(1) Key Laboratory of Horticulture Plant Germplasm Utilisation of the Ministry of Agriculture in Northwest China, Yangling, Shaanxi, 712100, People's Republic of China

(2) Key Laboratory of Agricultural Molecular Biology of Shaanxi Province, Northwest A \& F University, Yangling, Shaanxi, 712100, People's Republic of China

(3) College of Horticulture, Northwest A \& F University, Yangling, Shaanxi, 712100, People's Republic of China.

Submitted for publication: January 2009

Accepted for publication: May 2009

Key words: Chinese wild Vitis; powdery mildew; cDNA library; ESTs; Vitis pseudoreticulata

\begin{abstract}
Expressed sequence tags (ESTs) constitute a rapid and informative strategy for studying the gene expression profiles of specific stages of annual and perennial plant species. In the study undertaken for this report, a cDNA library was constructed from the young leaves of Chinese wild Vitis pseudoreticulata inoculated with Uncinula necator (Schwein.) Burrill. The leaves were harvested at various times after inoculation for total RNA extraction, which was used to generate ESTs. In our study, 107 cDNA clones were sequenced from either the 5' or 3' end of the cDNAs. Of these, 60 unigenes $(56.1 \%)$ were functionally characterised by the BLASTX matches to known-function proteins, and 20 unigenes $(18.7 \%)$ matched significantly with proteins with unknown function in the public databases. The remaining 27 unigenes $(25.2 \%)$ failed to show significant homology to any proteins in the public databases, suggesting that they represented novel sequences. Some functional genes identified from the cDNA library and their potential with plant defence system is discussed.
\end{abstract}

Powdery mildew of grapevines, caused by Uncinula necator, is a worldwide fungal disease. The pathogen is believed to have originated in North America and to have spread to Europe before 1850 (Pearson, 1988). Powdery mildew was observed in China for the first time in the 1950s (Wang, 1993). There have been reports of local powdery mildew disease outbreaks and potential for damage in the major grape production areas in China $(\mathrm{He}$, 1993; Wang, 1993; Wang et al., 1995; Zhang, 2001).

Grapevines (Vitis species) are cultivated commercially in more than 60 countries over a combined area of about 9 million ha (Anonymous, 1988). The leading cultivated species by far is Vitis vinifera L. It is supported by the multitude of uses of its fruit for producing table grapes, wine, juice and raisins. However, most of the European grape cultivars with a fine quality and high yield are susceptible to fungal diseases, which cause extensive losses in yield and quality. This has been the one of the most serious problems for grapevine cultivation. The most threatening among these fungi are powdery mildew, anthracnose, downy mildew, and grey mould rot. Powdery mildew is the most devastating fungal disease of grapevines worldwide, reducing yield, vine growth and vigour, and fruit quality (Pool et al., 1984; Gadoury et al., 2001).

Wild species are often valuable sources of resistance to crop pathogens. This is obviously the case for grapevine, where $V$. vinifera is susceptible to most pathogens whereas resistance to the same pathogens can be found in wild grapevine species (Boubals, 1959; 1961; 1966; Eibach et al., 1989). Among these wild species,
Muscadinia rotundifolia offers the highest level of resistance against the widest range of pathogens. Small (1913) proposed reclassification of Muscadinia as a distinct genus. The discovery that the chromosome numbers were different in Vitis $(2 \mathrm{n}=38)$ and Muscadinia $(2 \mathrm{n}=40)$ gave new support to this proposal (Branas, 1932). Programmes aimed at the introgression of resistance genes from $M$. rotundifolia into $V$. vinifera were developed (Wylie, 1871; Detjen, 1919a; 1919b), but have been limited by the high sterility of the hybrids (Patel \& Olmo, 1955; Nesbitt, 1966; Olmo, 1971; Bouquet, 1986). So, many international scientists undertake research on the resistance to Uncinula necator of grapevine using $V$. vinifera. Although a number of pathogenesis-related (PR) cDNA clones from $V$. vinifera cultivars Sultana and Cabernet Sauvignon infected with powdery mildew, such as chitinases (PR-2), beta1,3-glucanases (PR-3), and thaumatin-like (TL) proteins (PR-5), have been reported (Jacobs \& Robinson, 1999), the expression of chitinase genes in $V$. vinifera cultivar Ugni blanc induced by Uncinula necator has also been reported (Robert et al., 2002). In addition, a number of resistance gene analogs linked to a powdery mildew resistance locus in $V$. vinifera have been isolated (Donald et al., 2002). V. vinifera is not a desirable natural source of resistance to $U$. necator.

Consequently, it is desirable to identify natural sources of resistance to $U$. necator that might be employed to increase the resistance of cultivated vines. China is one of the major centres of origin of Vitis species (He et al., 1991). Chinese wild Vitis species 
are an important source of powdery mildew resistance, and these grapevine species originate from all parts of China. Chinese wild Vitis species are resistant to a number of pathogens known to affect cultivated grapevines, including powdery mildew, anthracnose, downy mildew, white rot and ripe rot (Wang et al., 1995; Wang \& He, 1997; Wang et al., 1998; Luo et al., 2002; Wang et al., 2002; Wang et al., 2003; Xu et al., 2003). In addition to their potential as sources of disease resistance, Chinese wild Vitis species do not have the foxy flavour that limits the use of some of the American native grapes in breeding programmes (Alleweldt \& Possingham, 1988). Therefore, they could provide an important source of resistance to a number of economically significant diseases. Understanding the host defence mechanism and identifying key genes in the resistant germplasm should provide valuable information and foundational resources for the timely and efficient molecular breeding of highly resistant cultivars.

In this study, in order to obtain more information about the interaction between host plant and pathogen at the molecular level of Chinese wild Vitis species in particular, and a cDNA library for study purposes was established using pilot-expressed sequence tags (ESTs). We undertook a moderate gene survey by means of the generation, sequencing and analysis of Vitis pseudoreticulata clone Baihe-35-1 ESTs, aiming to unveil new features and shed more light on lingering questions related to resistance, host interaction and molecular systematics of this species.

\section{MATERIALS AND METHODS}

\section{Plant materials and treatments}

V. pseudoreticulata clone Baihe-35-1 of the Chinese wild Vitis specie, which is highly resistant to powdery mildew and which is kept in the grape germplasm resources orchard, Northwest A\&F University, Yangling Shaanxi, People's Republic of China, was used in this study. The powdery mildew inoculation was carried out under natural field conditions. Before inoculation, the upper sides of the infected young leaves of Baihe-35-1 were pre-sprayed with sterile water. The upper sides of the leaves were then inoculated with spores by the dry-pressing method (Zhang et al., 2001). Spores were harvested from V. pseudoreticulata clone Baihe-35-1 leaves infected with Uncinula necator from 08:00 am to 10:00 am on 8 July 2003. The inoculated leaves were immediately covered with paper bags to prevent infection with other pathogens.

\section{Extraction of total RNA from $V$. pseudoreticulata clone} Baihe-35-1

At one, two, three, four, five, six and seven days post-inoculation, leaves were collected from $V$. pseudoreticulata clone Baihe-35-1 and snap frozen in liquid nitrogen. Total RNA was isolated from the above leaf samples with Zhang's SDS/phenol method (Zhang et al., 2003). The concentration of total RNA was estimated by measuring the O.D. in a spectrophotometer at $260_{n m}$.

\section{Construction of cDNA library}

The pool of total RNA from $V$. pseudoreticulata clone Baihe-35-1 at various times $(1 \mu \mathrm{g})$ was used to construct the cDNA library. According to the manufacturer's instructions, the synthesis of cDNA and an adaptor ligation were performed using the SMART $^{\mathrm{TM}}$ cDNA Library Construction Kit (CLONTECH, USA). The resulting cDNA was directly sub-cloned into the $\lambda$ TriplEx2 vector and packaged using MaxPlax ${ }^{\mathrm{TM}}$ lambda packaging extracts
(Epicentre Technologies) according to manufacturer's guidelines. The resulting primary library contained $3.0 \times 10^{5} \mathrm{pfu} / \mathrm{ml}$.

\section{Converting $\lambda$ TriplEx2 to pTriplEx2}

The conversion of a $\lambda$ TriplEx 2 phagemid to a pTriplEx 2 plasmid involved in vivo excision and circularisation of a complete plasmid from the recombinant phage. The $\lambda$ TriplEx 2 multiple cloning site (MCS) is located within an embedded plasmid (pTriplEx2), which is flanked by loxP sites at the $\lambda$ junctions. When the recombinant phage is transduced into Escherichia coli strain BM25.8, Cre recombinase is expressed in the E. coli BM25.8. In this system, the plasmid is released automatically as a result of Cre recombinasemediated site-specific recombination at the loxP sites. The excised plasmid is propagated stably in E. coli.

\section{Plasmid preparation}

A total of $2 \mu \mathrm{l}$ phage $\left(3.0 \times 10^{5} \mathrm{pfu} / \mathrm{ml}\right)$ was combined overnight with $200 \mu \mathrm{l}$ of BM25.8 host cell culture and the mixture was incubated at $31^{\circ} \mathrm{C}$ for $30 \mathrm{~min}$ without shaking. LB broth $(400 \mu \mathrm{l})$ was added to the mixture, which was incubated at $31^{\circ} \mathrm{C}$ for an additional $1 \mathrm{~h}$ with shaking $(225 \mathrm{rpm})$. Finally, the infected cell suspension was spread on a Luria-Bertani (LB)/ampicillin plate to obtain isolated colonies. Well-isolated colonies were randomly picked from each clone and plasmid DNA samples were prepared separately. The plasmid was prepared by using the Wizard ${ }^{\circledR}$ Plus SV Minipreps DNA purification system (Promega, USA). The plasmid DNA was stored at $-20^{\circ} \mathrm{C}$.

\section{Sequencing}

Purified plasmid DNA was sequenced to obtain the 5' end or 3 ' end sequence of the insert with a modified SMART primer (5'-CTCGGGAAGCGCGCCATTGTGTTGGT-3') or SP6 primer and Applied Bio-systems Big Dye Sequencing Mix. The sequencing reactions were separated on an Applied Bio-systems 3700 DNA analyser.

\section{Sequence editing}

Each sequence obtained was edited using Vecscreen (http:// www.ncbi.nlm.nih.gov) to remove flanking vector sequences and assessed manually to determine sequence quality. The author edited anomalous clone sequences manually after examination of their corresponding chromatogram files. Three classes of anomalous sequences were also excluded: (1) sequences without inserts at all; (2) sequences with reverse inserts; and (3) sequences with incorrect adapters.

\section{Homology comparisons}

Each edited EST was translated in all six reading frames and compared with the non-redundant database at the National Centre for Biotechnology (NCBI) using the BLASTX program, which compares translated nucleotide sequences with protein sequences. Default BLAST parameter values were used, except for the following settings: Expect $=1$, Alignments $=10$, and Descriptions $=10$. Sequences that returned no significant similarity were again compared using BLASTN, which compares nucleotide sequences with nucleotide sequences, with Expect $=1$, Alignments $=10$, and Descriptions $=10$. Homologies to negative reading frames were disregarded, except in clones with inserts in the reverse orientation. Putative identifications for the ESTs were assigned based on the results of the BLAST searches and, in some cases, with information contained in related abstracts in PUBMED. The non-redundant set 
of $V$. pseudoreticulata clone Baihe-35-1 ESTs was deposited in GenBank (GenBank accession nos. are AY848693; DQ336280336289; DQ339462-339464 DQ354157-354161; DT646287; DT661587-661592; DT661594-661601; DT661603; DT661605; DT661608; DT661610-661611; DT661613-661616; DT661618661619; DV182076-182078; DV182080-182082; DV182084182096; DV182098-182115; DV182117-182119; DV182121182135; DV671632-671634; DV671636-671638; DY242191).

\section{Analysis of ESTs}

cDNA sequences generated from each cDNA clone were carefully edited to remove the vector sequence and the low-quality sequences. ESTs longer than $150 \mathrm{bp}$ and containing no more than $4 \%$ ambiguity were considered useful for data analysis (Franco et al., 1995). Using the basic local alignment search tool (BLAST) service, at NCBI, sequences were subjected to search against the protein and nucleic acid databases. Sequence similarities identified by the BLAST programs were considered statistically significant at an $\mathrm{E}$ value of $\leq 10^{5}$.

\section{Semi-quantitative RT-PCR}

Using total RNA as template, one-step reverse transcription PCR was performed with M-MLV reverse transcriptase according to the manufacturer's instructions (Promega, USA). Primers of defencerelated genes and a reference gene were designed for semiquantitative RT-PCR (Table 3). PCR reactions were performed in a total volume of $25 \mu \mathrm{L}$ comprising $170 \mathrm{ng}$ DNA, $1.25 \mathrm{mM}$ dNTPs, $10 \mu \mathrm{M}$ of each primer, $37.5 \mathrm{mM} \mathrm{MgCl}_{2}$ and 0.2 unit of Taq DNA polymerase (Henan Sino-American Biotechnology Co., Ltd.). The PCR cycling conditions were an initial $94^{\circ} \mathrm{C}$ for $5 \mathrm{~min}$; 30 cycles of $94^{\circ} \mathrm{C}$ for $1 \mathrm{~min}, 56^{\circ} \mathrm{C}$ for $30 \mathrm{~s}$ and $72^{\circ} \mathrm{C}$ for $50 \mathrm{~s}$; and a final cycle at $72^{\circ} \mathrm{C}$ for $10 \mathrm{~min}$.

\section{RESULTS}

\section{Construction of $V$. pseudoreticulata clone Baihe-35-1 cDNA library}

The pool of total RNA from $V$. pseudoreticulata clone Baihe-35-1 at various times $(1 \mu \mathrm{g})$ was used to construct the cDNA library. The primary titre of the library was $3.0 \times 10^{5} \mathrm{pfu} / \mathrm{ml}$. The size of insert fragments basically ranged from $0.5 \mathrm{~kb}$ to $2.0 \mathrm{~kb}$, with an average of $0.9 \mathrm{~kb}$, and the recombinant phage in the library was $96.9 \%$.

\section{Characterisation of EST sequence}

The cDNA library generated from $V$. pseudoreticulata clone Baihe-35-1 was used as a source of ESTs. All ESTs from the cDNA library that were putatively identified from matches to database sequences of known functions were classified into general biochemical and metabolic functional categories (Table 1). The best matches for all the ESTs generated were to plant gene sequences, suggesting that none of the cDNA clones were copies of fungal mRNA. Of the $107 \mathrm{~V}$. pseudoreticulata ESTs isolated, $56.1 \%(60)$ possessed high sequence similarity to existing sequence entries of known function in the databases. The remaining $43.9 \%$ (47) represented sequences of no currently known function. Twenty of the 47 unknown ESTs (18.7\% of the entire sequenced cDNA library) were similar to sequences for genes coding for putative uncharacterised or hypothetical proteins. The remaining $17(15.8 \%$ of the whole cDNA library) did not exhibit sequence similarity to any known DNA or protein sequence in the databases. The known ESTs in this report were classified according to function as predicted by BLASTX (Table 1).

\section{TABLE 1}

Classification of ESTs according to function prediction by BLASTX match.

\begin{tabular}{lcc}
\hline Putative identification & $\begin{array}{c}\text { No. of } \\
\text { ESTs }\end{array}$ & $\begin{array}{c}\text { Percentage of } \\
\text { total (\%) }\end{array}$ \\
\hline Primary metabolism & 15 & $14 \%$ \\
Protein synthesis and sorting & 13 & $12.1 \%$ \\
Defence-related protein & 6 & $5.6 \%$ \\
Signal transduction and hormone & 5 & $4.7 \%$ \\
Secondary metabolism & 1 & $0.9 \%$ \\
Stress-induced protein & 2 & $1.9 \%$ \\
Cell wall structure and metabolism & 2 & $1.9 \%$ \\
Gene expression and chromatin metabolism & 4 & $3.7 \%$ \\
Transcriptional factor & 2 & $1.9 \%$ \\
Reactive oxygen & 3 & $2.8 \%$ \\
Membrane transport & 2 & $1.8 \%$ \\
Others & 5 & $4.8 \%$ \\
Unknown function & 20 & $18.7 \%$ \\
No match & 27 & $25.2 \%$ \\
Total & 107 & $100 \%$ \\
\hline
\end{tabular}

\section{Defence-related ESTs}

Seventeen ESTs were identified from the cDNA library to be potentially associated with plant defence responses. The level of redundancy of the defence-related ESTs was 15.8\% (Table 2), coding for specific antimicrobial proteins, signalling, receptors, protein kinase and defence-activating proteins. This search revealed sequence matches to cDNA clones/ESTs from related Vitis species or other organisms (Table 2), some of which were generated from stressed and disease-affected plant tissues.

\section{Analysis of semi-quantitative RT-PCR}

Semi-quantitative RT-PCR products were separated by electrophoresis in 1.0\% agarose/EB gel with GeneSnap from SynGene (Fig. 1). As Fig. 1 shows, these expression patterns in mRNA levels of chitinase, PAL, PPO, PR10, OAO, 4-CcoAL, HSP90 and MT gene compared to GAPDH displayed significant changes after the first day of inoculation. It depicts that these genes were involved in the resistant mechanism of powdery mildew.

\section{DISCUSSION}

To increase the probability of cloning the $V$. pseudoreticulata clone Baihe-35-1 transcripts involved in disease response, leaf tissue taken from a resistant $V$. pseudoreticulata plant (clone Baihe-35-1) was used for cDNA library construction, and the analysis was performed over a time span of seven days while under challenge from Uncinula necator. A random cDNA sequencing strategy was better than an mRNA differential display approach (Wang, 2004; Xu \& Wang, 2009). So, the use of an EST approach was a successful way of identifying genes in $V$. pseudoreticulata involved in a disease response to Uncinula necator. One hundred and seven ESTs from the cDNA library were identified. Of these, $56 \%$ were significantly similar to known gene sequences in entries in the databases searched. This value is higher than that observed in the analysis of cDNA libraries constructed from sugar 
TABLE 2

Potential V. pseudoreticulata defence-related ESTs matched with known genes of other organism.

\begin{tabular}{|c|c|c|c|c|c|}
\hline EST No. & Putative homologue & Organism & Accession No. & E value & Program \\
\hline VP422-5 & Class IV chitinase & Vitis vinifera & DT661595 & $2 \mathrm{e}-134$ & BLASTn \\
\hline VP285-5 & Gene for phenylalanine ammonia-lyase & Vitis vinifera & DV182110 & $5 e-06$ & BLASTn \\
\hline VP306-5 & RUB1 conjugating enzyme & Arabidopsis thaliana & DQ336285 & $7 e-90$ & BLASTx \\
\hline VP6-5 & Cysteine protease & Daucus carota & DV182129 & $1 \mathrm{e}-49$ & BLASTx \\
\hline VP189-5 & Polyphenol oxidase & Vitis vinifera & DV182119 & $2 \mathrm{e}-39$ & BLASTx \\
\hline VP278-5 & Oxalic acid oxidase & Brassica napus & DQ336283 & $5 e-35$ & BLASTx \\
\hline VP472-5 & Pathogenesis-related protein 10 & Vitis vinifera & DQ336289 & $8 \mathrm{e}-79$ & BLASTx \\
\hline VP141-5 & Cytochrome P450 & Panax ginseng & DV182125 & $2 \mathrm{e}-24$ & BLASTx \\
\hline VP68-5 & Cyclase family protein & Arabidopsis thaliana & DQ336281 & $2 \mathrm{e}-84$ & BLASTx \\
\hline VP336-5 & Putative receptor kinase & Solanum demissum & DQ336286 & $2 \mathrm{e}-05$ & BLASTx \\
\hline VP303-5 & Similar to serine/ threonine kinase 9 & Arabidopsis thaliana & DT661618 & $1 \mathrm{e}-07$ & BLASTx \\
\hline VP73-5 & 4-coumarate: coenzyme A ligase & Nicotiana tabacum & DV182129 & $8 \mathrm{e}-25$ & BLASTx \\
\hline VP272-5 & Heat shock protein 90 & Nicotiana tabacum & DV182112 & $5 e-111$ & BLASTx \\
\hline VP344-5 & Putative galactosyltransferase & Oryza sativa & DV182106 & $2 \mathrm{e}-36$ & BLASTx \\
\hline VP445-5 & Apiose/xylose synthase & Arabidopsis thaliana & DQ339463 & $1 \mathrm{e}-120$ & BLASTx \\
\hline VP7-3 & Metallothionein-like protein 1 (MT-1) & Cicer arietinum & DV182091 & $2 \mathrm{e}-08$ & BLASTx \\
\hline VP300-5 & Type 2 metallothionein & Arachis hypogaea & DV182094 & $3 e-15$ & BLASTx \\
\hline
\end{tabular}

TABLE 3

The pair of primers of defence-related genes and reference gene for semi-quantitative RT-PCR.

\begin{tabular}{lll}
\hline $\begin{array}{l}\text { Defence-related genes/ } \\
\text { reference gene }\end{array}$ & Upstream primer & Downstream primer \\
\hline GAPDH & 5'-AACATTGTGCCAACATCCA-3' & 5'-ACCCCATTCATTGTCATAC-3' \\
Chitinase & 5'-AGTCAGCTCGGGGTTTCA-3' & 5'-TGGAATCACAAATTTGTGTCT-3' \\
PAL & 5'-CGGTTAAATCATGATTATTTCC-3' & 5'-TCCAGAAACCAAATATAACCT-3' \\
PPO & 5'-GATACGGATTGGCTTGACG-3' & 5'-GGCCTTGGAACTTCTACTCTT-3' \\
PR10 & 5'-ATGGGTGTTTTCACTTACGA-3' & 5'-TTAATAGGCATCAGGGTGTG-3' \\
OAO & 5'-ATGTTTCTCCCAATTCTCTG-3' & 5'-TCATAATGTCACCCTTCTTAAG-3' \\
4-CcoAL & 5'-GTTCCAGTTGCATTCATTGT-3' & 5'-ACATGAAACATGTTATACATC-3' \\
HSP90 & 5'-ACATCGAAACCCTAAATCTC-3' & 5'-ATGAGATCCTTGAGTCGG-3' \\
MT & 5'-AGGTGACTGATCATTTTCTC-3' & 5'-TACACTGACCAAATACTAAGC-3' \\
\hline
\end{tabular}

cane leaf roll (38\%) (Carson \& Botha, 2000), various tissues and growth stages in rice (25\%) (Yamamoto \& Sasaki, 1997), maize leaf (20\%) (Keith et al., 1993) and Arabidopsis (32\%) (Newman et al., 1994). The analysis of ESTs in this study identified a range of genes likely to be involved in defence against pathogen attack, and provided some insight into the complex phenotype of powdery mildew resistance in Chinese wild Vitis species. By isolating cDNA from the leaf tissue of $V$. pseudoreticulata plant clone Baihe-35-1, challenged with Uncinula necator, this study aimed to enrich the cDNA library for the presence of defencerelated sequences so that a number of ESTs involved in defence responses could be identified. The enrichment process appeared to have been successful due to the relatively high number of defence- related ESTs identified (5.6\%) and the high level of redundancy of defence-related ESTs observed in this library. The number of ESTs from the V. pseudoreticulata plant clone Baihe-35-1 cDNA library that were tentatively identified as defence related was higher than that reported in a small library consisting of 250 sugarcane sequences. These were not enriched for defencerelated transcripts and it possessed only one EST $(0.4 \%)$ that was identified as defence related (Yamamoto \& Sasaki, 1997). However, in a cDNA library consisting of 430 clones constructed from fruits, peels and carpels from Fuji apple (Malus domestica Borkh.), 34 defence/stress-related ESTs were identified, which contributed to $7.9 \%$ of the library (Sung et al., 1998). Some of these ESTs were for genes that encoded proteins similar to 

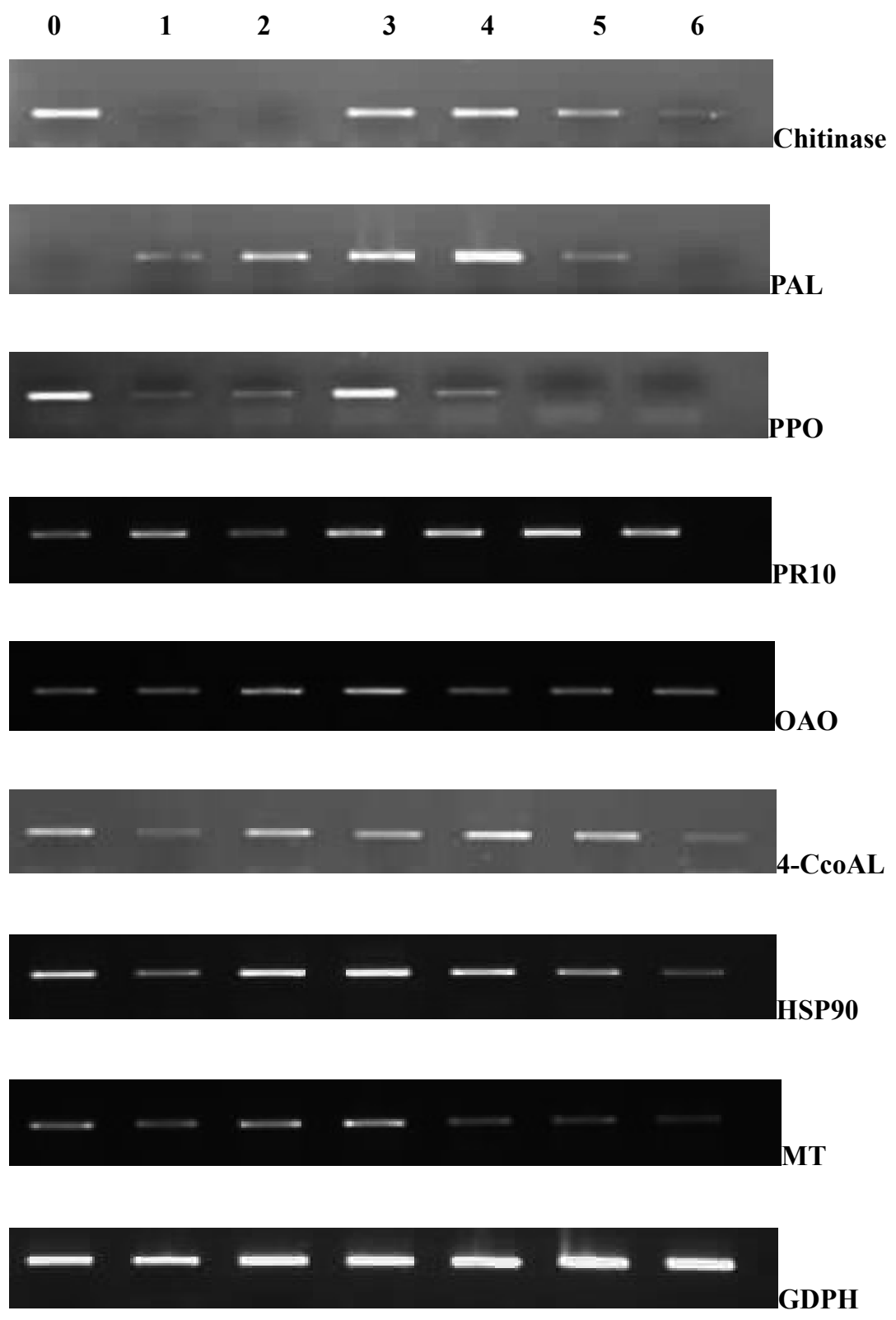

FIGURE 1

Expression patterns of chitinase, phenylalanine ammonialyase (PAL), polyphenol oxidase (PPO), pathogenesis-related protein (PR10), oxalic acid oxidase (OAO), 4-Coumarate coenzyme ligase (4-CcoAL), heat shock protein (HSP90) and metallothionein (MT) in different periods of inoculation. glyceraldehyde-3-phosphate dehydrogenase (GAPDH): a reference gene; 0: un-inoculated leaves; 1-6: leaves from one to six days after inoculation with Uncicula necator.

antioxidant enzymes, which Sung et al. (1998) suggested were needed to eliminate oxygen radicals to prevent the formation of the harmful lipid peroxide in the actively dividing cells and growing tissues of developing fruits. This indicated the importance of the type of tissue used to construct a cDNA library as a source of ESTs in order to identify ESTs related to disease response. In this study, the 17 unique potential defence-related ESTs represented genes coding for enzymes and proteins involved in different levels of defence, including recognition events between the plant and pathogen, signalling transduction and regulation, oxidative stress and the hypersensitive response, and specific defencerelated/pathogenesis-related proteins. Further analysis of gene expression on mRNA level indicated that chitinase, PAL, PPO,
PR10, OAO, 4-CcoAL, HSP90 and MT were involved in the resistant mechanism of powdery mildew (Fig. 1), and this result is consistent with previous studies on these genes in plant responses to abiotic and biotic stresses.

Two ESTs (VP422-5,VP472-5), representing pathogenesisrelated protein genes, encoded respectively for class IV chitinase and PR10 from Vitis vinifera, as were the ESTs for disease resistance response protein. Chitinase (EC 3.2.1.14), which degrades chitin, a $\beta$-1,4-linked homopolymer of N-acetyl-Dglucosamine (GlcNAc), is widely distributed in many species of higher plants. It has been postulated that plant chitinases play an important role in the defence mechanism against pathogenic fungi that contain chitin in their cell walls (Nasser, 1990). EST 
(VP472-5) shared similarity with sequences that encoded a PR10 from Vitis vinifera, The vast majority of proteins of the PR-10 family represent the products of genes that are expressed under influence of fungal and bacterial pathogens and show homology to pollen allergens from trees (Walter, 1996). There are a few reports that suggest that these proteins have ribonuclease function (Bantignies, 2000). It is supposed that PR10 proteins throughout the RNA degradation of pathogens might be involved in a defence mechanism in plants during pathogen attack.

Many end products of phenylpropanoid metabolism may also have direct antimicrobial effect, such as phytoalexins, resveratrol and flavonoids, or may serve to reinforce the cell wall, such as lignin. Three defence-related ESTs that encode for enzymes involved in the phenylpropanoid pathway (VP285-5 and VP735 separately showed strong similarity to PAL, 4-CcoAL) were identified from this cDNA library. The work of Langcake and Pryce (1977) on stilbenes showed that resveratrol was synthesised in grapevine in response to fungal attacks. These authors also considered as phytoalexins, all oxidation products of resveratrol as dimers, trimers and more highly polymerized oligomers of resveratrol, known as viniferins. It was shown that these phytoalexins were also produced in response to different biotic and abiotic stresses. Although these ESTs were expressed in resistant $V$. pseudoreticulata leaf tissue, further investigation is required to conclusively determine the function of this gene in Chinese wild Vitis plants (Jeandet et al., 2002).

Oxalic acid produced by this pathogenic fungus played an essential role in its pathogenic capabilities. During infection, the fungus produces high levels of a necrosis phytotoxin identified as oxalic acid. The role of oxalic acid in the pathogenicity process is still unclear. However, oxalic acid may have a number of functions in the infection process, including chelating calcium from the cell wall, thus making the pectic fraction more available to fungal hydrolases, and providing the acid $\mathrm{pH}$ needed for the maximum activity of the wall-degrading enzymes released by the pathogenic fungus (Keates et al., 1996). One part of the plant's defensive response to this may be the production of oxalate oxidase, which is an oxalic acid-degrading enzyme (Çalişkan, 1998). A better understanding of oxalate biology might enable us to manipulate various aspects of these organisms.

Furthermore, the sequence of EST VP272-5 was very similar to genes coding for heat shock protein 90 (HSP90). Heat shock protein ESTs were also abundant in the Cgm-Malva interaction, where the mRNA was extracted at the transition between biotrophy and necrotrophy (Goodwina et al., 2004). Heat shock proteins in the hsp70 and hsp90 families have been found to be related to host resistance and are believed to be involved in signal transduction for plant defence responses (Kanzaki et al., 2003).

The sequences of VP7-3 and VP300-5 aligned strongly with the genes encoding metallothionein-like (MT) proteins from plants. Inducible responses to heavy metals have been found for some plant MT-like genes, including two isoforms of MT-like genes in A. thaliana (Zhou \& Goldsborough, 1994) and an MT-like gene in Triticum aestivum L. (Snowden \& Gardner, 1993). Whereas the sequestration of metal ions released due to macromolecular degradation during senescence and hypersensitive responses in incompatible reactions (with pathogens) is a viable function for MT-like genes in plants, it may be more likely that metallothioneins are synthesised as protectants against the effects of oxidative damage. It has been proposed that MTs in animal tissues have a role in protection against the effects of reactive oxygen species by acting as antioxidants, since MTs are potent scavengers of hydroxyl radicals (Muira et al., 1997).

\section{CONCLUSIONS}

Our results show that the sequencing of ESTs from the $V$. pseudoreticulata plant (clone Baihe-35-1) library gives a global view of gene activities in the plant. The analysis of ESTs in this study identified a range of genes likely to be involved in defence against pathogen attack, and provided some insight into the complex phenotype of powdery mildew resistance in Chinese wild Vitis species. A number of sequences were identified as strong candidates for expression in $V$. pseudoreticulata as a defence response to Uncinula necator infection. Perhaps the most important group of ESTs identified in this study are those of unknown function. The ESTs making up this category may include previously uncharacterised defence and stress-related genes, which may be identified as the sequence databases continue to grow and by future microarray expression studies using the $V$. pseudoreticulata ESTs. On the other hand, ESTs are also useful as molecular markers for the construction of high-density genetic linkage maps. This is the first report of the analysis of ESTs from $V$. pseudoreticulata in a cDNA library and may have significant application for future studies on gene expression, mapping and genetic manipulation in $V$. pseudoreticulata.

\section{LITERATURE CITED}

Alleweldt, G. \& Possingham, J.V., 1988. Progress in grapevine breeding. Theoret. Appl. Genet. 75, 669-673.

Anonymous, 1988. The world viticultural situation in 1987. Bull. OIV 61, 749-804.

Bantignies, B., Séguin, J., Muzac, I.M., Dédaldéchamp, F., Gulick, P. \& Ibrahim, R., 2000. Direct evidence for ribonucleolytic activity of a PR-10-like protein from white lupin roots. Plant Mol. Biol. 42, 871-881.

Boubals, D., 1959. Contribution à l'étude des causes de la résistance des Vitacées au mildiou de la Vigne et de leur mode de transmission héréditaire. Ann. Amelior. Plant 9, 1-236.

Boubals, D., 1961. Étude des causes de la résistance des Vitacées àl'o de la Vigne et de leur mode de transmission héréditaire. Ann. Amelior. Plant 11, 401-500.

Boubals, D., 1966. Etude de la distribution et des causes de la résistance au Phylloxera radicicola chez les Vitacées. Ann. Amelior. Plant 16, 145-184.

Bouquet, A., 1986. Introduction dans l'espèce Vitis vinifera L. d'un caractère de résistance à l'o (Uncinula necator Schw. Burr.) issu de l'espèce Muscadinia rotundifolia (Michx.) Small Vignevini 12, 141-146.

Branas, M.M., 1932. Sur la caryologie des Ampélidées, C R Acad. Sci. Paris 194,121-123.

Çalişkan, M. \& Curning, A.C., 1998. Special specificity of H generating oxalate oxidase gene expressing during wheat embryo germination. The Plant Journal 15, $165-171$.

Carson, D.L. \& Botha, F.C., 2000. Preliminary analysis of expressed sequence tags for sugarcane. Crop Sci. 40, 1769-1779.

Detjen, L.R., 1919a. The limits in hybridisation of Vitis rotundifolia with related species and genera. North Carolina Agric. Exp. Stat. Bull. 17, 409-429.

Detjen, L.R., 1919b. Some $F_{1}$ hybrids of Vitis rotundifolia with related species and genera. North Carolina Agric. Exp. Stat. Bull. 18, 1-50.

Donald, T.M., Pellerone, F., Adam-Blondon, A.F., Bouquet, A., Thomas, M.R. \& Dry, I.B., 2002. Identification of resistance gene analogs linked to a powdery mildew resistance locus in grapevine. Theoret. Appl. Genet. 104, 610-618. 
Eibach, R., Diehl, H. \& Alleweldt, G., 1989. Untersuchungen zur Vererbung von Resistenzeigenschaften bei Reben gegen Oidium tuckeri, Plasmopara viticola und Botrytis cinerea. Vitis 28, 209-228.

Gadoury, D.M., Seem, R.C., Pearson, R.C., Wilcox, W.F. \& Dunst, R.M., 2001. Effects of powdery mildew on vine growth, yield, and quality of Concord grapes. Plant Disease $85,137-140$

Goodwina, P.H., Oliver, R.P. \& Hsiang, T., 2004. Comparative analysis of expressed sequence tags from Malva pusilla, Sorghum bicolor, and Medicago truncatula infected with Colletotrichum species. Plant Sci. 167, 481-489

He, P., 1993. Genetic studies of resistance to powdery mildew, in the $F_{1}$ generation of interspecific hybridization of Vitis. Intern. Symp on Horticultural Crop Improvement and Utilization, Beijing, China.

He, P.C., Wang, Y.J., Wang, G.Y., Ren, Z.B. \& He, C.C., 1991. The studies on the disease resistance of Chinese wild Vitis species. Scientia Agriculturea Sinica 24, $50-56$.

Jacobs, D. \& Robinson, 1999. Induction of different pathogenesis-related cDNAs in grapevine infected with powdery mildew and treated with ethephon. Plant Pathol. 48, 325-336.

Jeandet, P. Douillet-Breuil, A.C., Bessis, R., Debord, S., Sbaghi, M. \& Adrian, M., 2002. Phytoalexins from the Vitaceae: biosynthesis, phytoalexin gene expression in transgenic plants, antifungal activity, and metabolism. J. Agric. Food Chem. $50,2731-2741$.

Kanzaki, H., Saitoh, H., Ito, A., Fujisawa, S., Kamoun, S., Katou, S., Yoshioka, H. \& Terauchi, R., 2003. Cytosolic HSP90 and HSP70 are essential components of INF-1 mediated hypersensitive response and non-host resistance to Pseudomonas cichorii in Nicotiana benthamiana. Mol. Plant Pathol. 4, 383-392.

Keates, S.A., Zhang, D., Loewus, F.A. \& Franceschi, V.R., 1996. Oxalate oxidase is synthesized and secreted from bean leaf cells in response to fungal infection. Plant Physiol. 111, 311.

Keith, C.S., Hoang, D.O., Barrett, B.M., Feigelman, B., Nelson, M.C., Thai, H. \& Baysdorfer, C., 1993. Partial sequence analysis of 130 randomly selected maize cDNA clones. Plant Physiol. 101, 329-332.

Langcake, P. \& Pryce, R.J., 1977. A new class of phytoalexins from grapevines. Experientia 33, 151-152.

Luo, S.L., He, P.C., Zheng, X.Q. \& Zhou, P., 2002. Inheritance of RAPD markers in an interspecific $\mathrm{F}_{1}$ hybrid of grape between Vitis quinquangularis and $V$. vinifera. Scientia Horticulturae 93, 19-28.

Muira, T., Muraoka, S. \& Ogiso, T., 1997. Antioxidant activity of metallothionein compared with reduced glutathione. Life Sci. 60, 301-309.

Nasser, W., De Tapia, M. \& Burkard, G., 1990. Maize pathogenesis-related proteins: characterization and cellular distribution of 1,3- $\beta$-glucanases and chitinases induced by brome mosaic virus infection or mercuric chloride treatment. Physiol. Mol. Plant Pathol. 36, 1-14.

Nesbitt, W.B., 1966. Behavior of $\mathrm{F}_{1}$ hybrids of Euvitis cultivars and Vitis rotundifolia Michx. PhD dissertation, North Carolina State University.

Newman, T., De Bruijn, F.J., Green, P., Keegstra, K., Kende, H., McIntosh, L., Ohlrogge, J., Raikhel, N., Somerville, S. \& Thomashow, M., 1994. Genes galore: a summary of methods for accessing results from large-scale partial sequencing of anonymous Arabidopsis cDNA clones. Plant Physiol. 106, 1241-1255.

Olmo, H.P., 1971. Vinifera rotundifolia hybrids as wine grapes. Am. J. Enol. Vitic 22, 87-91.

Patel, G.I. \& Olmo, H.P., 1955. The hybrid $V$. vinifera $\times V$. rotundifolia. Am. J. Bot. $42,141-159$.

Pearson, R.C., 1988. Powdery mildew. In: Pearson, R.C. \& Goheen A.C. (eds.). Compendium of grape diseases. APS Press, St Paul, Minnesota. pp. 9 - 11 .
Pool, R.M., Pearson, R.C., Wesler, M.J., Lakso, A.N. \& Seem, R.C., 1984. Influence of powdery mildew on yield and growth of rosette grapevines. Plant Disease 68, 590-593.

Robert, N., Roche, K., Lebeau, Y., Breda, C., Boulay, M., Esnault, R. \& Buffard, D., 2002. Expression of grapevine chitinase genes in berries and leaves infected by fungal or bacterial pathogens. Plant Sci. 162, 389-400.

Small, J.K., 1913. Flora of the southeastern United States. New York: Publ. by the author.

Snowden, K.C. \& Gardner, R.C., 1993. Five genes induced by aluminum in wheat (Triticum aesticum L.) roots. Plant Physiol. 103, 855-861.

Sung, S.K., Jeong, D.H., Nam, J., Kim, S.H., Kim, S.R. \& An, G., 1998. Expressed sequence tags of fruits, peels, and carpels and analysis of mRNA expression levels of the tagged cDNAs of fruits from the Fuji apple. Mol. Cells 8, 565-577.

Walter, M.H., Liu, J.W., Wünn, J. \& Hess, D., 1996. Bean ribonuclease-like pathogenesis-related protein genes (YPR-10) display complex patterns of developmental, dark-induced and exogenous stimulus-dependent expression. Eur. J. Biochem. 239, 281-293.

Wang, X.P., 2004. Cloning and analyzing for the gene sequences of resistance to Uncinula necator in Chinese wild Vitis species. PhD dissertation, Northwest A\&F University, Yangling, Shaanxi, PR China.

Wang, Y., 1993. Genetic study on resistance to powdery mildew, Uncinula necator (Schw.) Burr., of wild Chinese Vitis species. PhD dissertation, North-western Agricultural University, Yangling, Shaanxi, PR China.

Wang, Y., Liu, Y., He, P., Chen, J., Lamikanra, O., \& Lu, J., 1995. Evaluation of foliar resistance to Uncinula necator in Chinese wild Vitis species. Vitis 34, 159-164.

Wang, Y.J. \& He, P.C., 1997. Study on inheritance of leaves' resistance to powdery mildew in Chinese native wild Vitis L. species. Scientia Agriculturea Sinica 30, 19-25.

Wang, Y.J., Liu, Y. \& He, P., 1998. Resistance of Chinese Vitis species to Elsinoë ampelina (de Bary) Shear. Hort. Sci. 33, 123-126.

Wang, Y.J., Xu, Y., Zhang, J., Peng, Z. \& Wan, Y.Z., 2002. Detecting RAPD markers linked to ripe rot resistance genes in Chinese wild Vitis. J. Agric. Sci. in China 1, 572-576.

Wang, Y.J., Zhang, J.X., Wang, X.P., Xu, Y. \& Wan, Y.Z., 2003. RAPD markers linked to the disease resistance genes in Chinese wild Vitis. Acta Horticulturae 625, 97-105.

Wylie, A.P., 1871. Hybridization of rotundifolia grapes. Am. Pomol. Soc. Proc. $13,113-116$.

Xu, Y. \& Wang, Y., 2009. Molecular cloning and characterization of novel heat shock protein 90 gene from a wild Vitis pseduoreticulata native to China. Biologia 64, 102-106.

Xu, Y., Wang, Y.J., Zhou, P. \& Zhang, J.X., 2003. Identification of molecular genetic marker tightly linked to white rot resistant genes in Chinese wild grape. Chinese J. Acta Hort. Sinica 30, 6-10

Yamamoto, K. \& Sasaki, T., 1997. Large-scale EST sequencing in rice. Plant Mol. Biol. 35, 135-144.

Zhang, J., Wang, Y. \& Xu, Y., 2001. The resistance of Chinese wild Vitis to Uncinula necator and its inheritance of $\mathrm{F}_{1}$ generation. Scientia Agriculturea Sinica 34, 610-614.

Zhang, J.J., Wang, Y.J., Wang, X.P., Yang, K.Q. \& Yang, J.X., 2003. An improved method for rapidly extracting total RNA from Vitis. J Fruit Sci. China 20, 178-189.

Zhou, J. \& Goldsborough, P.B., 1994. Functional homologs of fungal metallothionein genes from Arabidopsis. Plant Cell 6, 875-884. 